\title{
Cracking the Cultural Code of Gambling
}

by KATHRYN A. LATOUR, FRANCK SARRAZIT, ROM HENDLER, and MICHAEL S. LATOUR

International expansion by Las Vegas casino operators has so far been uneven, notably in Macao. Information on different cultures' understandings of gambling, which is scant, could be instrumental in supporting international expansion. Instead of using the common-macro level cultural comparison surveybased method, this research uses early childhood memory elicitation to focus on how individuals in three countries were initially exposed to gambling in their own families as children. This method is used to uncover the cultural code of gambling in the United States, the People's Republic of China, and France. The analysis indicates that each culture has its own code for gambling, a code that reveals that culture's gambling myth. These codes should help marketers understand the underlying motivations for gambling in each culture and should assist casino operators to market more effectively.

Keywords: gambling; childhood memory elicitation; cross-cultural studies; Las Vegas; Macao

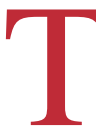
he effort by Las Vegas casino operators to export Las Vegas-style gambling to other areas of the world (notably, Macao, Singapore, and other Asian venues) raises the issue of the cultural underpinnings of gaming. MGM Grand, for instance, has developed a huge Las Vegas-style casino in Macao, while Las Vegas Sands suspended its planned development pending further financing (Loi and Kim forthcoming). Harrah's, the world's largest gaming company, has holdings in England and has indicated an interest in further European expansion (Stutz 2006). The Venetian Sands will open the first casino in Singapore, and other Asian countries are also seeking Las Vegas-style casinos (Barboza 2007).

Despite these developments, what works in Las Vegas may not necessarily work for other parts of the gambling world; for instance, though casino revenues have been high in Macao (until the recent recession), there was an initial "adjustment" needed as the Las Vegas companies found that the Chinese gambler wanted a different gambling experience than did the typical American gambler. In particular, these properties had difficulty meeting demand for the table games, which the Chinese prefer, while the slot areas sat virtually vacant. Likewise, the five-star restaurants were overlooked because the Chinese guests 
preferred fast fare they could eat without disturbing their gambling, and most of the Chinese gamblers did not even spend the night in a hotel room. Instead, the majority came to gamble (typically, on baccarat) all day and night (Barboza 2007). Recent revenue reports suggest that these companies are not meeting their profit expectations, and perhaps even greater attention to the local gamblers' needs may be necessary (Audi and Stanley 2008).

Cross-cultural research is complex, because there are many levels by which meaning is created for the customer. As McMillen $(1996,9)$ notes, while individual gambling behavior can be studied, it is instructive to recognize that modern gambling consumption is the result of "complex social relations lying beneath the surface," including the relationships of corporate gambling interests, societal expectations, personal perceptions of morality, and political and legal forces. In this article, we examine the many layers of meaning creation for gamblers in three cultures, namely, the United States, the People's Republic of China, and France.

The terms "gambling" and "gaming" have been used interchangeably to mean playing games of chance (American Gaming Association 2004). We see the growth of the term "gaming" as recognizing the entertainment and play aspect of gambling, particularly in the United States. Recognizing that other cultures experience gambling in a different way, we propose that an understanding of the socialization of play and gambling within the family structure is necessary (Rose 1999). We chose early childhood memory elicitation as the research methodology for this investigation because participants' retrieved childhood memories serve as a marker that combines cultural, family, and personal values (Braun-LaTour, LaTour, and Zinkhan 2007; Braun-LaTour and LaTour 2007).
These three different cultures represent divergent attitudes and beliefs regarding gambling (e.g., Hofstede 1980; Triandis 1994). The three cultures have rich but different gambling environments, as well as different notions regarding childrearing and religious practices that could influence views on gambling. Americans have traditionally been the largest tourist group visiting Las Vegas casinos, though the Chinese are coming often (and Macao represents more than a billion potential new gamblers). France has so far not been a main target for Las Vegas tourism. With its strong national gaming revenue and considerable leisure time, however, this country represents a potential new target for Las Vegas as well as for future development in Europe (Gu 2002).

The output of the childhood memory elicitation method is a "code" for each culture that, in this instance, represents how that culture's people approach their gambling experience (Rapaille 2006). An important aspect of this code is that it describes an underlying dimension based on how early experiences related to gambling have shaped the way people approach games in casinos. In essence, the cultural code determines the marketing and communication rules that must not be broken. The code also provides insight into the cultural myths about gaming (Holt, Quelch, and Taylor 2004; Woodside, Sood, and Miller 2008). The outcome of this study has implications specifically for the marketing of Las Vegas-style gambling worldwide and, more generally, for how companies might approach cultural differences to their product offering.

\section{Conceptual Background}

In its long history, gambling initially was tied to religion in the sense that fate was considered to be a proxy for the will of gods. In the seventeenth century, the 
secular idea of risk emerged (Reith 1999). Some historians argue that societal views towards gambling have evolved from a belief in providence (and religious institutions) towards a belief in chance (and market institutions) (Brenner and Brenner 1990). Despite its apparent universality, the meaning imputed to the concept of gambling depends on the sociohistorical contexts in which it occurs (McMillen 1996).

That context differs dramatically in the three cultures we are examining. In the United States, gambling began as part of the saloon experience and became associated with the nation's western expansion. The (eastern) Puritan-based culture attempted to control or ban gambling based on moral grounds but could not withstand the lure of easy money for both individuals and government. After Nevada legalized gambling in 1931, it was the only state with legalized gambling until 1976, when New Jersey legalized gambling in Atlantic City as a measure to restore its crumbling hotels. Casino gambling is now allowed in all but two U.S. states, either under state license or through arrangements with native American tribes. From 1992 through 2003, the U.S. casino industry saw its revenue more than double, from $\$ 10.2$ billion to more than $\$ 27$ billion. Americans spend more money in casinos than on movies or amusement parks (American Gaming Association 2004).

France has seen some type of gambling for at least the past eight centuries, and many casino games are thought to have their roots in France (e.g., blackjack, roulette, pari-mutuel). In the years surrounding the turn of the twentieth century, European gambling was closely linked with the aristocracy. With an emphasis on elegance, dignity, and refinement, casinos were palatial monuments. Following World War II, the French government began developing modern but spartan casinos that are generally much smaller than those in Las Vegas. French casinos face tighter government control, more regulations, and more taxes than those in the United States (up to a 56 percent tax rate compared to 6 percent in Nevada; Eadington 2007). Moreover, French casinos are limited to resort areas and cities having populations larger than one hundred thousand. France's two most famous casinos-Lyon Vert Casino, situated at Lyon; and Palais de la Mediterranée Casino, at Nice - are upscale gambling destinations (reflecting the aristocratic era of gambling). Gambling became more popular (and available) in France when slot machines were legalized in 1988. During the 1990s, the French casino industry had an average yearly revenue growth of 19.6 percent, the highest in Europe, while casinos on the Strip showed 6.7 percent growth (Gu 2002).

In contrast to the United States and France, gambling is forbidden in mainland China. There are regular propaganda campaigns in China against problem gambling (Papineau 2005). Most mainland Chinese play mahjong with family and friends (and bet on those games) or partake in the legal lottery, practices so widespread that they are not always viewed as gambling. The only region in China where gambling is legal, and formerly operated as a monopoly by Stanley Ho, Macao offered gambling for more than 150 years under Portuguese rule. Similar to the modern European casinos, the monopolistic situation resulted in relatively small, unimpressive looking casinos, and Macao's reputation was hurt by violence and organized crime (Strow 2002). In 1999, sovereignty of the island returned to China, and the island became more accessible to mainland Chinese gamblers. It was during this time that Macao decided to deregulate gambling and open it up to other casino 
operators. Three licenses were granted, one to Stanley Ho's enterprise and the other two to Las Vegas moguls Steve Wynn and Sheldon Adelson.

Several studies have reported that the Chinese are riskier gamblers and show greater illusion of control as compared to U.S. gamblers (Lau and Ranyard 2005). This illusion of control has been linked to pathological gambling behavior, and it appears that the Chinese rate of problem gamblers may be higher than with other ethnicities. Such an assertion is hard to support because many problem gamblers do not want to admit they have a problem, a face-saving practice particularly associated with the Chinese population (Blaszczynski, Huynh, and Dumlao 1998).

We have seen no in-depth research conducted as of yet to determine whether different cultures have different gambling motivations. Papinau (2005) discusses that Lesieur (1989) has been one of the few proponents of a cultural approach to gambling, quoting him (p. 159): "While providing an ethnographic base from which a bio-psychosocial theory may be developed, the sociocultural orientation holds promise. At present no studies compare the experiences of difference ethnic groups with gambling and pathological gambling in particular. Folk wisdom has it that ChineseAmericans are heavy gamblers, but there is no research on problem gambling among members of this ethnic group."

\section{Macro Views of Cultural Differences}

A top-down survey-based approach to cultural differences has pervaded the study of cross cultural behavior, with Hoftstede's (1980) five dimensions influencing how academic business researchers have looked at cultural differences. The dominant dimension focused on by marketing researchers in comparing Western European and Asian countries involves the individualistcollectivist mindset (Hofstede 1980). In individualistic cultures (like the United States and France), people tend to prefer independent relationships to others and to focus on their personal goals. In collectivistic cultures (like the People's Republic of China), people tend to prefer interdependent relationships to others and to subordinate their personal goals to those of their family (Hofstede 1980).

Of the numerous criticisms of the Hofstede approach to culture, perhaps the most telling point is that culture is too complex to be described in five dimensions. Instead, a holistic view of how culture, family, and the individual interact to create cultural constructs in the consumer's mind may be necessary when looking at individual product categories. In his own approach to cultural differences, French anthropologist Clotaire Rapaille (2006) reports on how using a bottom-up approach by investigating individual consumers' early childhood memories can be used to provide cultural insights, such as how American products are perceived abroad. For instance, he reports that French are viewed as "thinkers" who view Americans as childlike and naïve but at the same time extremely powerful. Rapaille does not discuss China or gambling, but his method is useful for our investigation.

\section{Early Childhood Memory Elicitation Method}

A cultural code is a mindset that influences how consumers interpret and respond to products and services (Rapaille 2006). Established in early childhood, the code is framed by the cultural environment in which one is raised. Generally the code is formed during late childhood (ages six to ten) and remains relatively stable throughout adulthood (Rapaille 2006). One cannot 
ascertain the cultural code through traditional surveys or interviews because it resides below people's awareness (Rapaille 2006). Members of a particular culture are usually oblivious to their code, but it strongly influences the things they do.

Until recently, the method for extracting the code was a closely held consulting "secret" held by Rapaille and associates. In 2007, coauthor Braun-LaTour and colleagues introduced the code-extraction method, childhood memory elicitation, to marketing academics and demonstrated its use in the context of automobiles (BraunLaTour, LaTour, and Zinkhan 2007). We have also published an article in the Cornell Quarterly demonstrating its application to hospitality (Braun-LaTour and LaTour 2007). The idea is that consumers' early childhood memories can be used as a projective technique to uncover consumers' underlying motivations and preferences. One psychologist who explored early memories (Wang 2001) found a cultural contrast between memories of U.S. students and Chinese students. The U.S. students' memories were earlier, more detailed, more emotional (particularly positive), and more self-focused than were the Chinese memories, which were more abstract and focused on family events. Other than Rapaille's unpublished consulting work, however, the study described here represents the first application of this method for uncovering cross-cultural differences in consumer behavior (and gambling in particular).

The early memory methodology is particularly well suited for looking at cultural differences. Socialization was one of the first topics addressed in cross-cultural research (Berry et al. 1992). Throughout the school years, children's memories are shaped by the narrative style espoused by their culture. Their experiences are grafted onto the meanings and markers of that culture. Zaltman $(2003$, 192) commented, "The culture a person grows up in strongly influences his or her brain's 'wiring,' or neural pathways, in the early years of life. The stories we hear starting in early childhood become important frames of reference or mental models that later influence the products and brands we buy, especially if stories about those brands resonate with deep cultural meanings embedded in our memories." According to Rapaille (2006), there are extremely strong imprints placed in the consumers' unconscious at this early age that are determined by the culture in which they are raised.

Thus far, most of the cross-cultural research on socialization has followed the individualist-collectivist perspective. Parents in individualist countries are more permissive and allow individual expression; whereas parents in collectivist countries are more controlling, attempting to meet social norms (Triandis 1994). Leading learning theorist Howard Gardner (1989) found differences in learning styles between the United States and China: in the United States, parents and teachers allowed the children to explore through trial and error to teach independence and prepare them to be creative problem solvers later in life; whereas in China, they valued "teaching by holding his hand," where the parent-teacher would carefully shape learning. In Chinese society children learn their place and learn to restrain personal desires for the benefits and interests of the collective.

France offers an interesting intersection of individualist-collectivist views of childrearing: French parents are concerned with their children being compliant and learning to conform to group values; they also promote their children's individuality through stimulation of the senses (Suizzo 2002). The French feel that Americans overly indulge and spoil their children. 
French parents believe in close, affectionate relationships between themselves and their children but also value self-control of emotions and are wary of too much closeness (Suizzo 2002).

\section{The Study}

We recruited participants with the assistance of the Venetian, a well-known Las Vegas resort casino. The goal was to find at least fifteen participants representing each culture, more than an appropriate size for the qualitative nature of the analysis (BraunLaTour, LaTour, and Zinkhan 2007). The sample included twenty-one U.S. gamblers, twenty-one Chinese participants, and eighteen French gamblers. They ranged in age from twenty-one to sixty-eight, representing both tourist and local players within each culture (see Exhibit 1, names disguised). Participants were given a $\$ 200$ gambling comp in exchange for participating in the two-hour session. To be considered for the study, a participant had to meet the following criteria: (1) have spent at least the first ten years of his or her life in the country of interest, (2) be raised in a household that spoke the country's native language (i.e., English, French, or Mandarin), and (3) consider himself or herself a "gambler." Note that we selected residents of mainland China because they represent the greatest potential for the Las Vegas casino operators in Macao, and they are quite different from Hong Kong Chinese.

Procedure. The forty-five-minute group session began with a short relaxation that included light yoga and breathing and visualization exercises (per Braun-LaTour, LaTour, and Zinkhan 2007). Using the participants'native language, the researcher guided them back in time to their earliest childhood, asking them to remember earlier and earlier points in their lives, providing them some guidance by referencing different time periods. Once they got to their earliest memories of gambling, they were asked to write down all the images, feelings, and words associated with that memory. They were guided to remember a childhood experience involving their favorite childhood game and to write down images and words associated with that memory.

Following the group session, participants went one at a time to an interview room, where they were asked to tell a story about their earliest memory of gambling. (There were three rooms with one-onone interviews occurring simultaneously; each interview lasted twenty minutes on average.) The interviewers sought details, such as how old participants were when the experience occurred, who else was involved in the memory, what sort of emotion or feeling was associated with the experience, whether any other memories were associated with gambling, and why they think they remembered that particular experience. When appropriate, the interviewers asked additional questions about the participants' thoughts and feelings about the differences between gambling in Las Vegas and gambling in their own country. They were also asked about their families' view of work and of gambling. They were asked about their religious views and how (and whether) they related to gambling. They were then asked to tell a story about their favorite childhood game. Additionally they were asked about how their families viewed play time. When they were done with their interviews (or waiting to be interviewed), they filled out a questionnaire that further encouraged them to describe their childhood memories.

Analysis. We accumulated twenty hours of taped interviews and four hundred pages from the questionnaires, which were translated and transcribed. The interpretation of 
Exhibit 1:

Sample Description

\begin{tabular}{|c|c|c|c|c|}
\hline $\begin{array}{l}\text { Name } \\
\text { (Gender) }\end{array}$ & Area Raised & Earliest Game & Earliest Gambling & Current Gambling Preference \\
\hline Li (M) & China & Sand bags & Mahjong, cards & $\begin{array}{l}\text { Blackjack (BJ), baccarat, } \\
\text { PaiGow, roulette }\end{array}$ \\
\hline Die (F) & Beijing & Water guns & Mahjong & BJ, poker, baccarat \\
\hline Anguo (M) & China & Reading, & Mahjong & BJ \\
\hline Fang (F) & China & Hide-and-seek & Mahjong, cards & BJ, baccarat \\
\hline Cai (M) & China & Pattle ball & $\begin{array}{l}\text { Visit to Japan } \\
\text { casino }\end{array}$ & Baccarat \\
\hline Bang (M) & Sichuan & Cartoon wars & Wei Qi (Go Game) & Poker, BJ, baccarat \\
\hline $\mathrm{Bao}(\mathrm{M})$ & Beijing & $\begin{array}{l}\text { Running and } \\
\text { soccer }\end{array}$ & Visit to Las Vegas & Baccarat, BJ, roulette \\
\hline Fei (F) & Jiang Su & Barbie doll & Mahjong & Baccarat \\
\hline Jiao (F) & China & $\begin{array}{l}\text { Rock, paper, } \\
\text { scissor }\end{array}$ & Mahjong & Slots \\
\hline Cong (M) & Fu Jian & Poker & Mahjong & Baccarat, poker \\
\hline Kake (F) & China & $\begin{array}{l}\text { Rubber band } \\
\text { jumping }\end{array}$ & Mahjong & Poker \\
\hline Kew (F) & Qing Dao City & Soccer & $\begin{array}{l}\text { Coin game at } \\
\text { arcade }\end{array}$ & Slots \\
\hline Dewu (M) & Jiang Si & Hide-and-seek & Poker & Pai gow, BJ, poker \\
\hline $\mathrm{Mi}(\mathrm{F})$ & Chong Qing & Monopoly & Mahjong & Baccarat \\
\hline Cheng (M) & Anhui & $\begin{array}{l}\text { Police catch } \\
\text { thieves }\end{array}$ & Mahjong & Poker, BJ \\
\hline Jie (M) & Chong Qing & Video games & Mahjong & Poker, BJ \\
\hline Kuo (M) & China & Military chess & Gambling in movies & Baccarat \\
\hline Mo Li (F) & China & Blindman's bluff & Poker & BJ \\
\hline $\mathrm{Li}(\mathrm{M})$ & Jinan & Cricket fighting & Cards & Baccarat, table games \\
\hline Xiu (F) & Suzhou City & Blindman's bluff & TV, dramas & Slots \\
\hline Yao (F) & China & Jump rope & Mahjong & Mahjong \\
\hline Jennifer & California & $\begin{array}{l}\text { Slot machine } \\
\text { bank }\end{array}$ & Poker & Video poker (VP) \\
\hline Amy & Chicago & Monopoly & Poker & VP \\
\hline Kevin & Chicago & $\begin{array}{l}\text { Trading sports } \\
\text { cards }\end{array}$ & Poker & Sports betting, poker \\
\hline Brian & Oklahoma & $\begin{array}{l}\text { Chinese check- } \\
\text { ers }\end{array}$ & Poker & BJ, craps \\
\hline Tom & Las Vegas & War (card game) & Poker & VP \\
\hline Melissa & Pennsylvania & Monopoly & Wheel, carnival & VP \\
\hline Elizabeth & Bronx & Monopoly, cards & Poker, BJ & VP, BJ \\
\hline Jack & Connecticut & Monopoly & Poker & VP, poker \\
\hline David & Kentucky & Uno, card games & Poker & VP \\
\hline Richard & West Virginia & Monopoly & Poker & VP, BJ \\
\hline Scott & California & Monopoly & Poker & VP \\
\hline Heather & Illinois & Monopoly & Horse racing & VP \\
\hline George & Brooklyn & Sette Mezzo & Poker & Poker \\
\hline Mark & Pennsylvania & Cards & Poker/pinochle & Slots, poker \\
\hline
\end{tabular}


Exhibit 1: (continued)

\begin{tabular}{|c|c|c|c|c|}
\hline $\begin{array}{l}\text { Name } \\
\text { (Gender) }\end{array}$ & Area Raised & Earliest Game & Earliest Gambling & Current Gambling Preference \\
\hline Stephanie & Boston & Cards & Las Vegas trip & BJ, poker, craps, VP \\
\hline Paul & Wisconsin & Monopoly & Church bingo & VP, slots, craps, BJ \\
\hline Lisa & Cleveland & Cards-Solitaire & Cards-father & $\mathrm{VP}$, cards \\
\hline Ryan & Wisconsin & Monopoly & Poker & Craps, BJ, poker, VP, slots \\
\hline Gian & Philadelphia & Monopoly & $\begin{array}{l}\text { Poker, sports bet- } \\
\text { ting }\end{array}$ & Sports betting, BJ \\
\hline Sarah & Chicago & $\begin{array}{l}\text { Board game-- } \\
\text { Parchese }\end{array}$ & Penny poker & VP, poker, BJ \\
\hline Steve & lowa & Cards & Poker & VP \\
\hline Amelie & Savoie & Board game & $\begin{array}{l}\text { Uncle playing at } \\
\text { casinos }\end{array}$ & VP \\
\hline Alain & France & Cards & $\begin{array}{l}\text { Poker, baccarat, } \\
\text { roulette }\end{array}$ & Poker, roulette, VP \\
\hline Alais & France & School games & $\begin{array}{l}\text { French casino, } \\
\text { twenty-seven }\end{array}$ & Poker \\
\hline Andre & France & Board games & $\begin{array}{l}\text { Casino trip, late } \\
\text { adolescence }\end{array}$ & VP \\
\hline Bibi & Sete & $\begin{array}{l}\text { Games with } \\
\text { cousins }\end{array}$ & $\begin{array}{l}\text { Casino in Baden } \\
\text { Baden }\end{array}$ & VP \\
\hline Franck & Bordeaux & Soccer & Marbles & Poker, VP \\
\hline Henri & Nice & Board game & $\begin{array}{l}\text { Walk by casino with } \\
\text { father }\end{array}$ & Poker, roulette \\
\hline Luc & Paris & Cards & $\begin{array}{l}\text { Parents went to } \\
\text { casino }\end{array}$ & VP \\
\hline Gigi & Fountainebleau & Board game, six & $\begin{array}{l}\text { Watch grandmother } \\
\text { cards }\end{array}$ & Slots and roulette \\
\hline Pierre & Nice & Cards & Walking by casino & VP \\
\hline Rene & Grenoble & Board game & Parents go to casino & VP \\
\hline Margot & Lyon & $\begin{array}{l}\text { Board game, } \\
\text { marbles }\end{array}$ & $\begin{array}{l}\text { Watch grandmother } \\
\text { tierce }\end{array}$ & VP \\
\hline Emile & $\begin{array}{l}\text { South of } \\
\text { France }\end{array}$ & Board games & Marbles & Slots \\
\hline Noelle & Paris & Board game & $\begin{array}{l}\text { Walking past bar } \\
\text { tabac }\end{array}$ & Poker \\
\hline Laurent & $\begin{array}{l}\text { Northeast } \\
\text { France }\end{array}$ & Cards & TV shows & Slots \\
\hline Josette & Charentes & Cards & $\begin{array}{l}\text { Playing card with } \\
\text { daughter }\end{array}$ & Slots \\
\hline Eloise & France & Cards & $\begin{array}{l}\text { Parents played at } \\
\text { casino }\end{array}$ & VP \\
\hline Deni & Paris & Cards & Vacation & VP \\
\hline
\end{tabular}

the memory stories was discovery-oriented, in keeping with the experience of Rose et al. (1998), who found such exploratory analysis particularly important for crosscultural research. In keeping with earlier procedure, the memory stories were analyzed 
on two levels. The literal level recorded the age when the memory took place and the type of experience involved. In the mythic level (Dichter 1964; Levy 1981), the childhood memories of game playing particularly are open for interpretation, as noted by Smith and Abt $(1984,123)$ : "The world of play and games offers a varied menu of rituals, myths, icons, and heroes that articulate, reinforce, and transmit cultural values in a manner very similar to that of religion." These authors also note that childhood and adolescent games bear similarities to later adult gambling behavior.

The approach to the data analysis is grounded in rigorous interpretive procedures, including individual analysis, numerous iterations, and part-to-whole comparisons. After reading and hearing the participants' memory stories, we discussed and developed a series of cultural codes. Typically such codes are described in one word. So, for example, the code for car might be power. As Hirschman (1986) pointed out, the identification of the code is often associated with a gestalt insight. Once the code was identified, we reviewed the reports from each culture to verify that the code informed most of the participants' stories. In this presentation of the data as a means to demonstrate the code as lived by the participants (emic level), short summaries as well as a few longer stories about early exposure to gambling are included. It is openly stated that the voice of the researchers is in the presentation of the codes (etic level).

Characteristics of the childhood memories. The sessions were successful in eliciting childhood memories of gambling and other games (as summarized in Exhibit 2). The average age of the gambling exposure was 6.9 in the United States, 9.1 in China, and 8 in France. While there were some idiosyncratic experiences mentioned (such as Jack's remembering a father "running numbers" in Connecticut), most U.S. participants (seventeen) said that their earliest exposure to gambling had taken place at either their home or a relative's home where the grown-ups played poker around the kitchen or dining table. Feelings of home, comfort, food, warmth, togetherness, and celebration characterized these positive memories. Several participants said it felt like "there was a casino in my house," because there were always card games like poker and gin rummy going on. For many others, though, the gambling took place after a holiday meal or on a certain night of the week and had ritualistic undertones (note that while the memories were about family, the "self" was the focus).

The Chinese participants had similar early recollections of card games, but the game of choice there was mahjong, and their memories revolved around "others," as in Yao's memory:

\section{My family would play mahjong on special festival days. We would play for hours. Before we knew the rules of the game we as children would make up our own and imitate our parents and grandparents as they played. We didn't play for money, but for ice cream.}

As found in earlier research, the Asian parents appeared to "protect" their children from gambling exposure (compared to U.S. parents), as revealed through their older age of exposure. Also consistent with prior research, this study found the Chinese recollections to be less emotional and detailed than those from the United States and France. The Chinese participants had never gambled in a casino in China (because none exists), so their exposure to gambling only occurred in private homes. Only one of the participants had gambled in a casino in Macao, while the rest had their casino experiences in the 
Exhibit 2:

Cultural Codes and Implications

\begin{tabular}{|c|c|c|c|}
\hline Country & Code & Myth & Implications \\
\hline $\begin{array}{l}\text { United } \\
\text { States }\end{array}$ & Winner & $\begin{array}{l}\text { Horatio Algier's } \\
\text { American } \\
\text { dream, anyone } \\
\text { can be a winner }\end{array}$ & $\begin{array}{l}\text { Re-create warmth but competitiveness from childhood } \\
\text { family games by offering tournaments } \\
\text { Help gamblers build rituals to their behavior } \\
\text { Focus on winners and their "everyman" status in } \\
\text { promotional materials } \\
\text { Tie into aspirational aspect in loyalty programs, } \\
\text { demonstrate in casinos what higher tiers get } \\
\text { Provide an exciting atmosphere } \\
\text { Focus on quick, fast returns }\end{array}$ \\
\hline France & Mastery & $\begin{array}{l}\text { Pascal's view that } \\
\text { one can use } \\
\text { math and } \\
\text { intellectual } \\
\text { capabilities to } \\
\text { outsmart } \\
\text { system }\end{array}$ & $\begin{array}{l}\text { Recognize that gambling was restricted during childhood } \\
\text { so there is not the same positive warm memories as } \\
\text { U.S. and China; perhaps playing off this restriction } \\
\text { would make it more acceptable (such as an ad saying, } \\
\text { "What your parents didn't want you to know" showing } \\
\text { a couple in austere clothing with serious expressions } \\
\text { putting their children to bed and then opening the door } \\
\text { to a casino in their house) } \\
\text { Appeal to intellectual side of masters (e.g., crack the } \\
\text { code of poker) by offering educational opportunities so } \\
\text { they can learn to "beat the system" } \\
\text { Highlight the intellectual background of past winners } \\
\text { Appeal to their sense of superiority by offering exclusive } \\
\text { areas with dress codes } \\
\text { For those nonmasters, highlight how in games of chance } \\
\text { even a nonmaster can win } \\
\text { Foster a sense of ownership in the games by touting } \\
\text { roulette's connection to France (and that of other } \\
\text { games) }\end{array}$ \\
\hline China & Distinction & $\begin{array}{l}\text { Dostoyevsky's } \\
\text { Alexi, gamble } \\
\text { to death, } \\
\text { overcome social } \\
\text { obstacles or } \\
\text { repression, the } \\
\text { need to exist as } \\
\text { an individual } \\
\text { and have the } \\
\text { attention on } \\
\text { oneself }\end{array}$ & $\begin{array}{l}\text { Recognize the conflict between their government's view } \\
\text { of gambling and their own need to advance in society } \\
\text { Appeal to their egos and need for status by having } \\
\text { premium tables with observation decks } \\
\text { Know the Chinese gambler does not believe they win } \\
\text { because of mastery (as do the French) but rather } \\
\text { because of luck, so incorporate "lucky" aspects into the } \\
\text { casino design } \\
\text { Focus on the status that winning can buy-showcase } \\
\text { past winners who have used wealth to advance their } \\
\text { family's status } \\
\text { Recognize that losses at the table are ego losses, and } \\
\text { offer ways to save "face" (such as ways to try and } \\
\text { recoup losses) }\end{array}$ \\
\hline
\end{tabular}


Exhibit 2: (continued)

\begin{tabular}{ll}
\hline Country Code & \multicolumn{1}{c}{ Implications } \\
\hline & $\begin{array}{l}\text { To broaden appeal beyond the serious table players, tie the } \\
\text { into feelings of freedom in childhood and early play in the } \\
\text { outdoors, reframe gambling as "gaming" and highlight } \\
\text { social nature of mahjong and transfer to machine games } \\
\text { designed for social interaction }\end{array}$ \\
\hline
\end{tabular}

United States during their late adolescence or early adulthood.

Unlike U.S. and Chinese participants, many of the French respondents' memories occurred outside of the home, such as Monique's recollection of walking the streets of Paris with her mother and inquiring about the long line of people waiting to validate their Tiercé (a horse racing bet). Others recalled being at local fairgrounds and watching individuals trying their luck at the pusher machines (in which people insert coins at the top and watch as they drop on to trays). Similar to U.S. and Chinese participants, French respondents' earliest exposures to gambling happened in the company of their parents. Dissimilar to the U.S. and Chinese memories, though, was that many of the French memories involved feelings of rejection (rather than acceptance). Henri clearly remembers walking the "promenade des Anglais" in Nice with his dad every week. However, he never got to go inside with his dad, as he would normally be taken to watch a movie with other family members while his dad visited the casino. He remembered thinking, "What do they do without me? Did I do something wrong?" Bibi also described the same experience of "exclusion" attached to casino visits. She had traveled to Baden-Baden when she was twelve years old, only to be "left behind in the cafeteria." Because French parents did not expose their children to casinos directly, many, like Rene, mentioned watching casinos in James Bond movies or other TV programs that made gambling seem elegant and exciting.

There were both similarities and differences in childhood-play memories for the three cultures. These memories generally occurred before or during the same time period as the gambling memories, age 6.1 in the United States, 7.2 in China, and 7 in France. Overwhelmingly the games of choice for the U.S. participants were Monopoly and card games. Participants remembered the colorful money used in Monopoly and taking money when another player landed on his or her property. They reported liking the challenge of these games. Both types of games were frequently played with families (immediate and extended) in a "friendly" competition. The competition theme underscored these recollections. The U.S. participants remembered their parents teaching them cards as a means to make them smarter than their competition (preparing them for school or jobs). These types of games refer to a strategic element of game playing, which has influence on their choice of gambling games later on.

Popular board and card games also were often cited as spontaneous earliest 
memories associated with gambling for the French group. Le Jeu de L'oie ("game of the goose," where virtue is rewarded and vice punished), Petits Chevaux (a racing board game), and well-known card games (e.g., belotte, Rami, tarot) were described as synonymous with family entertainment, moments of fun, and togetherness. The French participants noted having the most free play time as children. Most participants also noted the competitiveness and winning aspects of these games. Yet they added that these did not involve real money- "We were not playing for money" (Josette) - and reflected a time of innocence (Alais).

The Chinese parents were much more restrictive with play time than were the U.S. and French parents - participants said that school and homework always came first and that they could play if their work was complete. Several participants began by saying that their parents "didn't control them," but then went on to list all the restrictions imposed around their play (such as time of day, who they could play with). Dewu recalled,

They did not allow me to go out to play during the noon, because in my hometown, most of the people like to take a nap during the noon; my parents did not want to go out to play at noon, worrying about I was going to ruin neighbors' nap. Also they did not allow me to play with water; they think it is too dangerous.

One extreme example came from Bang, who recalled playing a game where he would win hundreds of paper men and then get into "wars" with his friends. $\mathrm{He}$ became quite good at this game and collected thousands of these paper men in a box. His parents burned that box because they thought it was frivolous and wanted him to concentrate his time on studying. Also in contrast to the United States, most
Chinese respondents associated their early play with being outside and playing hide-and-seek; rubber band jumping; or rock, paper, scissors. Some said they did not have many options for toys, and the games they most recalled were these outside games. One participant recalled being quite happy as a child, only to be deported to the rural countryside during Mao's Cultural Revolution, which he said "took away his childhood." Being inside was associated with being restricted; in fact, Fei remembers having both her parents working and being locked inside her home by herself to play alone with her Barbie doll. There was an overall feeling of nostalgia associated with their early childhood memories. Many yearned for that early time without today's stresses, particularly since Chinese children are given a great deal of responsibility at an early age because they need to bring honor to their families.

\section{The Cultural Codes}

The Americans: Winner. The code for gambling in the United States is winner, particularly from an underdog or everyday hero perspective (again, see Exhibit 2). The idea is embodied in the Horatio Alger stories in which impoverished protagonists overcame numerous obstacles to build their own American dream. This same American dream resonates today in popular TV shows like American Idol, where anyone has a chance to "win" and make it big. Though the gamblers understood that the odds were against them, they rationalized their choice to gamble by saying, "Someone here [in the casino] is going to win; why not me?" This seemed to rectify the conflict with their Puritan work ethic, where the concept of chance is at odds with views of gaining a reward for hard work - which all of the U.S. gamblers espoused. Ryan recalled going with 
his father to a tavern after he had completed his chores and the feeling that his father must be rich to be able to bet money on cards. Truth to tell, they were not rich. As farmers, finishing one's work before the gambling could begin was an important point.

The competitive nature of the childhood games transmitted to how they felt about gambling. It was not so much about the money (though that was not unimportant), but the idea of being better than everyone else was prized. Being a winner is the identity the American gambler seeks, and the money is proof that they are successful. The U.S. respondents could recall the exact amounts of money they won in games in their childhood (down to the penny). This focus on winnings was not found in the other cultures. For example, Heather recalled the emotion of winning her bet:

Harness racing at the Iowa County Fair in September 1974. My whole family would get together and pick playing cards with numbers that would be the horse you had. It was a $\$ 1.00$ bet. I won $\$ 50$ as a child, and thought I was in heaven!!!

The idea of winning and the accompaniments associated with it (e.g., comps, parking places) were also tied to the "exclusiveness" of gambling that made it seem special to these respondents. For instance, several participants recalled going with their parents to the VFW Hall, where they had to be buzzed in or know the secret code to get in and gamble. As children they were "allowed" to watch their parents gamble. The memories were aspirational in that the participants remembered wanting to be able to play but either were too young or did not yet know the rules of the game. Scott recalled there being a kids' table where they would play card games, and as they got older and learned more games, they were able to move up toward the adult games (and relished beating the adults). This feeling of coming of age (which was much younger than casino age limits, usually around age twelve) and being able to beat others signified an important point in the participants' journey from youth to adulthood. When they got to the adult table, they "felt like an adult" (Heather), and feelings like pride and boastfulness were also indicated.

The U.S. gamblers were the most religious of the three groups, although they came from various religious backgrounds. Many U.S. respondents did not see a separation between gambling and religion. While some traditions frowned on gambling, some respondents thought the Catholic church supported or embraced gambling. Several participants fondly remembered church bingo and casino nights. In fact, one participant, Melissa, had her first job at church bingo and felt a pride in that job because her aunts and mom played and she felt like she was "in the know." Another Catholic (George) recalled carrying a bible and deck of cards around in his pockets in Brooklyn, New York, not really knowing the difference between the two. A few others associated their Sundays (a religious day for Christians) with gatherings for gambling, either watching football games and playing the lines or having the aforementioned family poker games.

Many in the U.S. group gambled because of "boredom." They lacked challenges in their daily lives, but winning in the casino gave them a feeling of control over their destiny. They used gambling in a recreational sense to escape daily responsibilities. Even a small win on the machines or the tables gave them a sense of power over their lives. There was an excitement to winning, and some of their recollections carried exclamation marks (!!!) along 
with such comments as "Whoo!" "Yeah!" "Winner!" Joanna recalls the sense of exhilaration with her first memory:

My family plays poker after all holiday dinners. I was allowed to watch as a young child. At approximately eight years I was allowed to play with my own money. I was an extreme saver and kept an old cigar box full of coins. The first time I pushed my pennies on the table I was scared, and I almost cried when I lost. However, when I won the pot, I was ecstatic and loved the feeling.

The rush of the victory is critical, and this ties into the atmosphere of the Las Vegas casinos, where bright lights, noise, fun, and excitement become part of the equation, as the casinos celebrate you (the winner). The adrenaline rush is part of what Rapaille (2006) considers to be the logic of emotion, an important and necessary part of the U.S. gambling experience.

The French: Mastery. French has no word for gambling. The closest is jouer de l'argent, which means "playing some money." Gambling is therefore automatically associated with money. The French teach the value of money early on, but in a more negative way than in the United States. For instance, French parents say, "You have to be careful with money." The French educational system, furthermore, teaches students to be "conservative." The stated purpose for their schooling is to get a job, in contrast to the American dream, where children are told anything is possible. French children learn not to play with money, while early on the Americans are given substantial access to what money the family has available. For example, U.S. children are given money for good behavior or gifts, and American children ages four through twelve accounted for $\$ 6.1$ billion in purchases in 2001 (see Chudacoff 2008).
American children use their Monopoly money for currency in games of play, like having a pretend store.

Several French participants recalled gambling for the first time with marbles either with siblings or with classmates. Alais referred to marbles as "wise games." Another recalled that she lost all the time as a child to her brothers and later learned that they had cheated. She says she now "knows the game" (as in casino play) and knows how to win. Franck recalled,

I think I was five or six. I would go to school with ten marbles in my pocket and come home with fifteen. I learned very quickly how to beat my schoolmates at marbles. It takes agility and skill. I remember enjoying counting my marbles at the end of the day.

Looking at these and other recollections, we determined that the code for gambling in France is mastery. This view has historical roots in France, back to Pascal's Gambler, who thought that mastering probability theory would provide insights into how a gambler must bet. Mastery is also represented in Casanova, who ran France's lottery and was interested in learning the inner workings of the system and managing it, which he felt set him apart from the masses that actually played it (Kavanaugh 2005). Like the U.S. respondents, the French gamblers enjoyed the competition in their youth. Instead of the American focus on winning, though, the French focus was on not losing and using their superior mind to crack the system (a prevention frame). This was explicitly expressed by Rene: "I really hated to lose"; and Gigi: "It was annoying to lose." This group felt that they were more detached than the U.S. gamblers in their gambling style and thus could take a more "rational" or logical perspective to their gambling decision 
making, perhaps because they did not have the emotional or family connection to gambling as did the U.S. and Chinese gamblers. Mastery is a way of convincing themselves that they are doing nothing wrong, that is, playing with money in an acceptable way.

The French gamblers learned early on that gambling required study. Margot described her grandmother carefully studying her newspaper (for race statistics). "She was trying to win money; it did not look like pleasure; she was studying. There was no communication with her, and she would ask us to be quiet." This serious aspect linked to potential gains and combined with a theme of rejection was also described by Gigi, who, at five years old, remembered her great grandmother playing some card game with friends every afternoon, "and with money." She remembered "the seriousness of her [grandmother's] face" and thinking that "something important and big was happening." She was not allowed to sit at the table as it was "an adult game" but thought this was aspirational: "I thought this was very professional, something I'd be doing when I am older, like the godfather movie." She recalls that her great grandmother was strategic in her play and stingy with her wins ("protective" of her money). There was no cheating allowed in the game; rules were closely followed. Pierre remembers, after his father would not allow him into the casino in Nice,

My father brought home a small case that contained all the casino games in it (like roulette and blackjack). It was a toy kit. He didn't teach me how to gamble but rather what a gamble was, not about winning or losing, just about the rules.

The French believed they were not egoinvolved (which they consider to be the case for U.S. gamblers) and could distance themselves from the emotion of play. Eloise compares Americans to "grown-up children who play the game," as opposed to French players who are "taking the fun out of playing." This is echoed by Alain, who explains that the French "do not play to play." As a result, many of the French describe a good gambler as someone who can "control" the way he or she plays. "It is someone who knows when to stop" (Josette) or "knows how much he can afford to lose then leaves" (Bibi). This informs the atmosphere, as noted by Margot: "people communicate less in French casinos; they keep to themselves; if they win they do not jump around or shout like as the case here [Las Vegas]."

The code mastery can also imply eliteness or superiority. Bibi expressed the notion of materialistic "superiority" from gambling. She possesses a "black card," a symbol representing her status as "president of the club" and giving access to some perks (e.g., preferred rooms, limo service to the airport, dinners). She tends to favor the games that earn her "good points," which in turn help her maintain her status as president.

Most of the French participants were raised as Catholics and, unlike U.S. participants, readily recognized that their religion does not value gambling. However, most felt inherent religious views did not affect their own attitudes toward gambling. Education and work ethics seem to be more important aspects to consider. Alain explains that the French value work as long as it provides "a better quality of life." It is acceptable to earn good money through work but less "acceptable" to gamble one's money, as it bears many risks. Eloise explained that "someone who plays a lot cannot make a living out of it." However, there are cases when gambling is more extreme, as in the case of the 
French rogue trader who was playing with money (and gambling that he would not get caught). To the world's surprise, he never directed the fraudulent cash to a personal account - he thought be could outsmart (master) the system.

The Chinese: Distinction. The code for gambling in China is distinction, for which their gambling was a symbolic portrayal of risk-taking that was tied to their self worth. Of the three cultures, the Chinese showed the closest resemblance to what Jung (1919/1970) called the "gambler archetype." Indeed, we see the Chinese as being much like Dostoyevsky's Gambler. Dostoyevsky's Alexei is a prototypical gambler who rationalizes and defends his growing obsession with roulette. For Alexei, a big win at roulette would earn him entrance into the aristocracy and transform him from outsider to insider. Alexei ultimately gambles all his fortunes away but felt that his risk taking was ennobling.

China's emerging focus on capitalism is in conflict with Confucianism, which states, "If one's action is guided by profit, one will incur much ill will." The Chinese government's restriction on gambling, while punishing visible party members for their gambling behavior, puts gamblers in an interesting paradox: one shouldn't gamble and risks being punished for gambling, yet it is one easy path to getting ahead in Chinese society. The casino offers a place to transcend class and reality. The purpose of a myth is to provide a logical model capable of overcoming a contradiction (Levi-Strauss 1977), and the contradictions found in the Chinese culture with respect to views on gambling appear to drive their Gambler myth.

According to Jung's energetic perspective of the gambling archetype, gambling is an attempt to outrun the speed at which ordinary change happens. Acquiring great wealth in a casino in one throw of the dice or by winning the lottery is a spectacular experience not only because of the money but because of the experience of the compression of time. In that regard, Fang told us that gambling makes you forget things you don't like, and she reports "getting caught up in the moment" with blocks of time lost.

Jiao says most Chinese gamblers keep gambling when they are losing because they think it is because of bad luck that eventually will change. Mo Li says Chinese gamblers want more if they win; if they lose, they place more bets and are eager to win back; but in most cases they lose. The long persistence in play harkens back to their childhood game playing, which would often go on for days and would involve socializing and feelings of freedom (Cong). The only time their culture allows for such indulgence in adulthood is on holidays (notably, Chinese New Year), and mahjong play can go on for days during these festivities.

The Chinese take gambling seriously. When the Chinese became "of age" to gamble, there was a strong pressure to win and the game became less recreational. While the U.S. (and French) participants viewed work as a means for self-expression and to "get ahead," almost all of the Chinese participants said their family wanted them simply to find a stable job. One said their "goal is to find a job that isn't too tiring." Another said, "Money is not the goal of working - don't need to open one's own business or be well known through one's work."

When money started to become involved in the card games, there was less interest or focus on the process of gambling and more concern on the result. For instance, Li recalled an early gambling experience 
where an older child approached him and set forth a contest to see whose cricket could chirp the loudest. Li used sticks and taunted his cricket to chirp louder, and in cases where that did not work and he lost, he would throw his cricket in the air, killing it when it hit the ground. The violence in this recollection, which is dramatic (and negative) compared to the U.S. and French memories, suggests that there is a greater cost to gambling in China.

Unlike the U.S. participants (but similar to the French), the early gambling memories of the Chinese were passive, more about observing and learning than focused on the action or movement as seen in the U.S. recollections. Because of the complexity of mahjong, there was a feeling that one needed to watch, learn, and own the game. Like the French, Chinese respondents wanted to master their game. Bang, for example, said that taking a third-person viewpoint allowed him to look at the game from a broader perspective so he could learn how to anticipate moves. But unlike the French, where mastery was the goal, the point of gambling for the Chinese was to use this mastery to "show off" their gambling skills and win money. As Bang says, "The main purpose of this is not gambling but pride."

We found the Chinese family view of gambling to be complex. Overall there was a negative view, where many participants recalled hearing stories about people who had lost their property, jobs, and families (and even taken their own lives) because of gambling debts. One even said that her family thought gambling was "evil." Another said, "Gambling has one hundred negatives and not one positive," and "gambling can ruin lives." This negative viewpoint was considered the "traditional" way of thinking in Communist China.
Despite this view, many of the families did gamble at home at cards, and some even had ventured into casinos, though most of the gambling occurred in private rather than public spaces. Bang felt that there was pressure centered on gambling in China because the gambling occurred in the home (and could be scrutinized by relatives), and that led to more pressure because it was seen as unacceptable behavior. Control or lack of control was seen as a major factor in Chinese gambling - most participants thought it was OK to gamble with small amounts of money. They thought, however, that gambling with large amounts showed lack of control. There is a Chinese proverb that says, "A little gambling is soothing and relaxing; heavy gambling could affect your mental health." In fact some feared that, because gambling had always been so restricted in mainland China, if it became legal the Chinese people could not handle it and would lose control. When asked what they thought was the difference between U.S. and Chinese gambling, this idea of control also came out. The participants felt that in the U.S. gambling is for recreation and entertainment. Given that U.S. gamblers have lots of choices to serve that entertainment need, the Chinese respondents thought Americans do not take gambling as seriously as Chinese gamblers do. Many used the terms "open" or "free" to describe U.S. gambling and "closed" to describe Chinese gambling.

Almost all the Chinese claimed no religious views. Since their cosmogony does not inform them of a creator (God), their language has no word for sin (or for the wrath of God) that would conflict with gambling. Nevertheless, a large proportion of our Chinese respondents believed in a type of providence, usually ghosts, spirits, or "luck" (in the form of superstition). For example, Yao says he 
always washes his hands before he gambles, and if he is doing poorly gambling, he touches his shoes so his bad luck can "walk away." Li believes if his left eyelid twitches, good luck is coming his way; if his right eyelid twitches, then bad luck is coming his way. Even though the Chinese gamblers did not subscribe to a religion, five admitted that they pray for good luck when they gamble.

Relationship to current gambling preference. Exhibit 1 summarizes participants' current casino games of choice. Participants were asked in the interviews whether they noticed a relationship between their childhood memories and their current gambling. In the case of the U.S. participants, the most obvious relationship was the early exposure to playing poker and current game choice of live or video poker in casinos. Most poignant was Melissa, who had fond memories of her mother and family gambling at carnivals and church bingo. She reported feeling good about gambling despite her first husband's committing suicide because of a large gambling debt. Two participants (Amy and David) said their parents were big gamblers and always talked about coming to Las Vegas but never got the chance. These two respondents felt it was somewhat ironic that they personally live there now (achieving their parents' dream).

The French gamblers' game of choice depended on whether they thought themselves to be a master (where they chose games like poker, video poker, or blackjack) or if they felt they had not mastered gambling (in which case they turned to games of chance such as traditional slots and roulette). Either way, their aspiration level aligned with their level of mastery of gambling. For example, Gigi says she prefers games of chance because "I don't have to think. I fear I am not a good gambler." She recalls having a roulette wheel game in her home when she was six, but she did not understand the game then. She thinks back about those memories when she plays roulette now. Alain also enjoys roulette, as that was one of the games he was exposed to early by his parents. He recalls being fascinated by the numbers and in his interview repeated his "lucky" numbers. Rene, for instance, is a master who prefers games like poker and blackjack:

As a kid I played cards and learned to count cards. It was a good memory tool when you're a kid. But now in the casino I know the games I have a chance to win, and I'm not going to play against the casino. I know the statistics and know that the big jackpots don't happen often. How do you think they built Vegas? I want to play for myself.

The masters seem to prefer the games that are intellectual and involved, which might indicate a level of intellectual superiority through mastery of the game. Alais likes playing cards "because it makes my brain work." Noelle favors the games "she can control" so that she can "come back home with money-their money." Margot prefers video poker or card games because "you feel you are in control as you can select the cards you keep," unlike traditional slot machines where "the machine does it all."

Our findings were consistent with other studies in that Chinese players prefer table games (Loi and Kim forthcoming). This finding supports that individualistcollectivist view of gambling behavior, since the Chinese were much more interested in social games (like baccarat) than individual games (like slot machines). At the baccarat table, players shout when peeling back their cards - and all attention is paid to the gambler Lam (2007). This meets 
the needs of the Chinese for social recognition where they can show off their gambling prowess. (Baccarat also involves considerable chance, rather than skill.) The Chinese interest in these types of games seems to stem from a communal background that highlights social interaction and their culture's views of luck, fate, and destiny. The few Chinese players who preferred machines liked the ones based on chance (rather than video poker, which requires some decision making).

\section{Implications}

How gambling was socialized into a culture influences how it is currently perceived. The different cultural codes observed in this study provide insights into the marketing of gambling to these different groups. Based on our research and analysis of childhood memories, we offer the following marketing implications (also summarized in Exhibit 2).

We noticed that each group has different views of time. The U.S. winner is heavily in the moment, seeking the promise of immediate gains. The French master is less rushed. Everything is calculated, and it is the outcome that counts. Therefore, a French gambler prefers games of less "intensity" that can span a longer time. By contrast, in addition to gaining social distinction as a gambler, the Chinese use gambling to lose track of time (or to compress it) and to disassociate themselves from their daily life stresses. Thus, they prefer games that are highly engaging. We observe that despite a clear relationship between early memories and current gambling activities, the codes transcend the context of the game. That is, different codes might lead gamblers to the same game, but for different reasons. For instance, U.S. participants might choose video poker because of their competitive upbringing, whereas French participants like that game because they feel they can learn how to beat the system.

\section{Marketing Approaches}

The Americans. A key marketing approach for American gamblers is to be aware of their need to celebrate their status as winners. Thus, one can tie into aspirational aspects in loyalty programs and demonstrate the casino's rewards for higher tiers of players. Casinos can provide an exciting atmosphere by offering tournaments and focusing on winners' "everyman status" in promotion materials. Given their fond childhood memories of gambling (at home), one approach would be to re-create that warmth along with the competitiveness. Likewise, just as gambling was a ritual in childhood, casinos can help gamblers build rituals for their adult behavior.

The French. Marketing to French gamblers should appeal to their mastery of the game, including educational opportunities so that can learn the "crack the code" of poker. For those who do not yet feel mastery of the game, casinos should offer games of chance that anyone can win - or better yet, games where one can learn to develop a "system." Marketing appeals should focus on quick returns and highlight the intellectual accomplishments of past winners. In contrast to the American situation, French gamblers generally do not have warm childhood memories of gambling, because they were restricted from games of chance. One way to play off this restriction might be to focus on how gamblers have now "arrived," and therefore know information that their parents attempted to suppress. Exclusive areas in the casino will appeal to their sense of superiority, and touting games connected to France (notably, roulette) will evoke a feeling of ownership in the games. 
The Chinese. The key points for marketing to residents of mainland China is to address the social nature of gambling and to realize the conflict inherent in gambling - that is, the government's ban on gambling as against the gamblers' need to advance in society. To promote the distinctive status of the high-rolling gambler, a casino should offer premium tables that include observation areas. Showcasing past winners also builds the status concept. Unlike the French, who focus on the technical aspects of the game, Chinese gamblers generally believe in the influence of luck, which argues for incorporating "lucky" aspects into casino design. Since gambling losses involve the person's ego, the casino should offer ways to save face, perhaps by proposing ways to try and recoup losses. Finally, it might be possible to tie the into feelings of freedom of early childhood play by reframing gambling as gaming and to highlight machine games designed for social interaction.

Childhood connections. Las Vegas is known as an adult Disneyland and its marketing exploits the tie between childhood game playing and adult gambling play. The commercialization of play is yet another way in which culture both influences and reflects the culture that contains it. In addition to demonstrating the relationship between a person's current gambling preferences and one's early childhood play and gambling exposure, this study shows that differential socialization of gambling changes its meaning from one culture to another.

More broadly, this research demonstrates how the childhood memory elicitation method can be used to provide cross-cultural insights. In contrast to the dominant research approach of investigating individualistic-collectivistic differences, the benefit of the early childhood memory technique is that it is educes what is most important for consumers. (See Exhibit 3 for a comparison of forms of qualitative research.) Finding the "code" is important because the human brain is not open to all new information. Consumers process novel information in terms of their experiences and how the new item meets their personal goals. A cultural code provides the key to these neural networks.

Finding ways to break through filtering mechanisms to learn about consumers' desires is essential to the marketing process. Childhood memory elicitation can provide the needed deep insights that are unlikely to come from traditional research methods like surveys and focus groups. In this regard, we note the method's ability to connect with the deep memories of our Chinese respondents. Other researchers have discussed the difficulty in getting Chinese to "open up" in marketing research sessions (Blaszczynski, Huynh, and Dumlao 1998). Although we note a comparative lack of detail in the Chinese memories, the childhood memory elicitation method did offer a personalized view of their gambling.

Marketing research efforts by the casinos in Macao have employed traditional research methods that have not yielded the deeper motivations unearthed here. We cannot necessarily compare the findings from this Las Vegas-based sample to Macao's gamblers, however. This is a limitation to our findings: the participants had all been to Las Vegas and arguably preferred that style of gambling. We also note that the role and presence of online gaming is likely to change the playing field. Cotte and LaTour (2009) report that online gambling is experienced quite differently than casino gambling, and the meanings also change in that context. 
Exhibit 3:

Comparison of Qualitative Methods of Obtaining Cross-Cultural Insight

\begin{tabular}{|c|c|c|c|c|}
\hline & $\begin{array}{c}\text { Childhood Memory } \\
\text { Elicitation Method }\end{array}$ & $\begin{array}{l}\text { Ethnographic } \\
\text { (Observational) }\end{array}$ & $\begin{array}{c}\text { Depth (or Life } \\
\text { History) Interview }\end{array}$ & Focus Group \\
\hline $\begin{array}{l}\text { Length of } \\
\text { interview and } \\
\text { sample } \\
\text { considerations }\end{array}$ & $\begin{array}{l}120 \text { minutes (with } \\
3 \text { video cameras), } \\
20 \text { participants per } \\
\text { session, depending on } \\
\text { research issue one to } \\
\text { three groups } \\
\text { recommended }\end{array}$ & $\begin{array}{l}\text { Days or weeks, } \\
\text { depending on the } \\
\text { research topic, } \\
\text { can focus on an } \\
\text { individual family } \\
\text { or larger store or } \\
\text { hotel context, so } \\
\text { sampling issues } \\
\text { vary }\end{array}$ & $\begin{array}{l}3 \text { to } 5 \text { hours } \\
\text { (or more), per } \\
\text { participant, } \\
\text { generally } \\
\text { need } 8 \text { to } \\
10 \text { participants }\end{array}$ & $\begin{array}{l}90 \text { minutes, } \\
\text { generally } \\
8 \text { to } 10 \\
\text { participants } \\
\text { per session } \\
\text { (and usually } \\
\text { run } 3 \text { or } \\
4 \text { sessions) }\end{array}$ \\
\hline Cost factors & $\begin{array}{l}\text { Economical use of } \\
\text { moderator and facility } \\
\text { time; video equipment } \\
\text { and transcription costs }\end{array}$ & $\begin{array}{l}\text { Generally no } \\
\text { overhead because } \\
\text { "out in the field" } \\
\text { but large } \\
\text { participant fees; } \\
\text { may need video } \\
\text { and audio } \\
\text { equipment and } \\
\text { transcription } \\
\text { service }\end{array}$ & $\begin{array}{l}\text { Extensive use of } \\
\text { moderator and } \\
\text { facility time, } \\
\text { more expensive } \\
\text { per interview, } \\
\text { large } \\
\text { transcription } \\
\text { costs }\end{array}$ & $\begin{array}{l}\text { Economical } \\
\text { use of } \\
\text { moderator } \\
\text { and facility } \\
\text { time, some } \\
\text { transcription } \\
\text { costs }\end{array}$ \\
\hline Time factors & $\begin{array}{l}\text { Economical use of time } \\
\text { for interviewing because } \\
\text { can be run in groups of } \\
20, \text { moderate time for } \\
\text { analysis since focus on } \\
\text { earliest and defining } \\
\text { memories rather than } \\
\text { whole life span }\end{array}$ & $\begin{array}{l}\text { Extensive time for } \\
\text { observation, } \\
\text { substantial } \\
\text { volume of data } \\
\text { produced making } \\
\text { analysis longer }\end{array}$ & $\begin{array}{l}\text { Extensive time } \\
\text { for interviewing } \\
\text { and substantial } \\
\text { volume of data } \\
\text { produced, } \\
\text { making analysis } \\
\text { longer }\end{array}$ & $\begin{array}{l}\text { Economical } \\
\text { use of time } \\
\text { for interview } \\
\text { and analysis }\end{array}$ \\
\hline $\begin{array}{l}\text { Stimuli involved } \\
\text { in session }\end{array}$ & $\begin{array}{l}\text { Relaxation and memory } \\
\text { walk, usually run in a } \\
\text { facility with mats, } \\
\text { blankets, etc. available }\end{array}$ & $\begin{array}{l}\text { Idea is to observe } \\
\text { in natural setting, } \\
\text { so nothing special } \\
\text { needed }\end{array}$ & $\begin{array}{l}\text { Depends, can } \\
\text { take place in } \\
\text { home or place } \\
\text { of purchase, } \\
\text { flexible }\end{array}$ & $\begin{array}{l}\text { Flexible, ads } \\
\text { or other } \\
\text { marketing } \\
\text { materials } \\
\text { can be } \\
\text { shown }\end{array}$ \\
\hline Output & $\begin{array}{l}\text { Video montage of } \\
\text { participants' earliest and } \\
\text { defining memory stories, } \\
\text { identification of key } \\
\text { themes, code identified, } \\
\text { also can identify social } \\
\text { and cultural events } \\
\text { associated with product, } \\
\text { interpretation of the } \\
\text { memories for insight into } \\
\text { brand meaning }\end{array}$ & $\begin{array}{l}\text { Analysis quality } \\
\text { dependent on the } \\
\text { training or } \\
\text { experience of the } \\
\text { researcher, large } \\
\text { amounts of data } \\
\text { to sort through, } \\
\text { so practical } \\
\text { implications may } \\
\text { not be readily } \\
\text { apparent }\end{array}$ & $\begin{array}{l}\text { Life history of } \\
\text { participant, can } \\
\text { track how tastes } \\
\text { and preferences } \\
\text { have evolved } \\
\text { over a lifetime }\end{array}$ & $\begin{array}{l}\text { Top-of-mind } \\
\text { reactions, } \\
\text { report } \\
\text { summarizing } \\
\text { what people } \\
\text { say about } \\
\text { product or } \\
\text { service }\end{array}$ \\
\hline
\end{tabular}


Exhibit 3: (continued)

\begin{tabular}{|c|c|c|c|c|}
\hline & $\begin{array}{l}\text { Childhood Memory } \\
\text { Elicitation Method }\end{array}$ & $\begin{array}{l}\text { Ethnographic } \\
\text { (Observational) }\end{array}$ & $\begin{array}{l}\text { Depth (or Life } \\
\text { History) Interview }\end{array}$ & Focus Group \\
\hline Strengths & $\begin{array}{l}\text { Uncovers important } \\
\text { memories that } \\
\text { consumers may have } \\
\text { forgotten, good for } \\
\text { identifying nostalgia or } \\
\text { emotional connections, } \\
\text { deep insights }\end{array}$ & $\begin{array}{l}\text { Observation takes } \\
\text { place on-site or } \\
\text { where the product } \\
\text { is consumed, so } \\
\text { factors associated } \\
\text { with layout, } \\
\text { design, etc. can } \\
\text { easily be } \\
\text { addressed }\end{array}$ & $\begin{array}{l}\text { Great depth in } \\
\text { interpreting } \\
\text { brand or } \\
\text { product use for } \\
\text { a given } \\
\text { consumer }\end{array}$ & $\begin{array}{l}\text { Quick, } \\
\text { inexpensive }\end{array}$ \\
\hline Weaknesses & $\begin{array}{l}\text { Shorter interviews, so no } \\
\text { perspective of how } \\
\text { memory experiences } \\
\text { “fit" into the } \\
\text { consumers' life, } \\
\text { researcher needs to } \\
\text { understand nuances of } \\
\text { memory }\end{array}$ & $\begin{array}{l}\text { Analysis quality } \\
\text { dependent on the } \\
\text { training or } \\
\text { experience of the } \\
\text { researcher, not } \\
\text { getting to the } \\
\text { deeper "whys" } \\
\text { about what } \\
\text { people do (deeper } \\
\text { motivations) }\end{array}$ & $\begin{array}{l}\text { Because of the } \\
\text { great depth, } \\
\text { sample usually } \\
\text { is small, } \\
\text { marketing } \\
\text { connections } \\
\text { vary dependent } \\
\text { on strength and } \\
\text { interpretation of } \\
\text { the researcher }\end{array}$ & $\begin{array}{l}\text { Social } \\
\text { desirability } \\
\text { bias, quality } \\
\text { much } \\
\text { determined } \\
\text { by strength } \\
\text { of moderator, } \\
\text { lack of depth, } \\
\text { superficial } \\
\text { insights }\end{array}$ \\
\hline
\end{tabular}

\section{References}

American Gaming Association. 2004. 2004 state of the states: The AGA survey of casino entertainment. Washington D. C.: American Gaming Association.

Audi, Tamara, and Bruce Stanley. 2008. U.S. casinos stumble over new business model in high-stakes Macau market. Wall Street Journal, May 22, p. B.1.

Barboza, David. 2007. Asian rival moves past Las Vegas. New York Times, January 24, p. B1.

Berry, John W., Ype Poorting, Marshall H. Seagall and Pierre R. Dasen (1992), Cross-Cultural Psychology: Research and Applications. Cambridge,UK: Cambridge University Press.

Blaszczynski, Alex, S. Huynh, and V. J. Dumlao. 1998. Problem gambling within a Chinese speaking community. Journal of Gambling Studies 14 (4): $359-80$

Braun-LaTour, Kathryn A., and Michael S. LaTour. 2007. Using childhood memory elicitation to gain insights into a brand at a crossroads: The In-N-Out burger situation. Cornell Hotel and Restaurant Administration Quarterly 48 (3): 246-73.

Braun-LaTour, Kathryn A., Michael S. LaTour, and George M. Zinkhan 2007. Using childhood memories to gain insight into brand meaning. Journal of Marketing 71 (April): 45-60.

Brenner, Reuven, and Gabrielle Brenner. 1990. Gambling and speculation. Cambridge: Cambridge University Press.
Chudacoff, Howard P. 2008. Children at play: An American history. New York: New York University Press.

Cotte, June and Kathryn A. LaTour (2009), "Blackjack in the Kitchen: Understanding Online Versus Casino Gambling," Journal of Consumer Research, 35 (5), $742-758$

Dichter, Ernst. 1964. The handbook of consumer motivation. New York: McGraw-Hill.

Eadington, William R. 2007. Gambling Policy in the European Union: Monopolies, Market Access, Economic Rents, and Competitive Pressures among Gaming Sectors in the Member States. Working Papers 07-005, University of Nevada, Reno, Department of Economics \& University of Nevada, Reno, Department of Resource Economics.

Gardner, Howard. 1989. Learning Chinese-style. Psychology Today 23 (12): 54.

$\mathrm{Gu}$, Zheng. 2002. Diversity into European markets to enhance revenue: A strategy proposed for the Las Vegas Strip and Atlantic City. UNLV Gaming Research \& Rw Journal 6 (2): 43-52.

Hirschman, Elizabeth C. 1986. Humanistic inquiry into marketing research: Philosophy, method and criteria. Journal of Marketing Research 23 (August): 237-49.

Hofstede, Geert. 1980. Culture's consequences: International differences in work-related values. Beverly Hills, CA: Sage.

Holt, Douglas B., John A. Quelch, and Earl L. Taylor. 2004. How global brands compete. Harvard Business Review, 82 (9) September, pp. 68-75. 
Jung, Carl G. 1919/1970. Collected works, Civilization in transition, vol. 10. Edited and translated by Gerhard Adler and R. F. C. Hull, Princeton, NJ: Princeton University Press.

Kavanaugh, Thomas M. 2005. Dice, cards, wheels: A different history of French culture. Philadelphia: University of Pennsylvania Press.

Lam, Desmond. 2007. An observation study of Chinese baccarat players. UNLV Gaming Research \& Review Journal 11 (2): 63-73.

Lau, Lai-Yin, and Rob Ranyard. 2005. Chinese and English probabilistic thinking and risk taking in gambling. Journal of Cross-Cultural Psychology 36:621.

Lesieur, H. R. 1989. Current research into pathological gambling and gaps in the literature. In Compulsive gambling: Theory, research, and practice, ed Howard J. Shaffer, Sharon A. Stein, Blase Gambino, and Thomas N. Cummings 225-48. Lexington, MA: D.C. Heath.

Levy, Sidney. 1981. Interpreting consumer mythology: A structural approach to consumer behavior. Journal of Marketing 45 (Summer): 49-61.

Loi, Kim-Ieng, and W. G. Kim. Forthcoming. Macao's casino industry: Reinventing Las Vegas in Asia. Cornell Hospitality Quarterly.

McMillen, Jan. 1996. Understanding gambling: History, concepts and theories. In Gambling cultures: Studies in history and interpretation, ed. J. McMillen. London: Routledge.

Papineau, Elisabeth. 2005. Pathological gambling in Montreal's Chinese community: An anthropologic perspective. Journal of Gambling Studies 21 (2): $157-78$.

Rapaille, C. Clotaire. 2006. The culture code. New York: Broadway Books.
Reith, Gerda. 1999. The age of chance: Gambling in Western culture. London: Routledge.

Rose, Gregory. 1999. Consumer socialization, parental style, and development timetables in the United States and Japan. Journal of Marketing 63 (3): 105-19.

Rose, Gregory, Mei C. Alonzo, Aviv Shoham, and Frederic Kropp. 1998. The inherent role of exploration in cross-cultural research. In American Marketing Association conference proceedings, vol. 9, 221. Chicago: AMA.

Smith, James F., and Vicki Abt. 1984. Gambling as play. Annals of the American Academy of Political and Social Science 474:122-32.

Strow, D. 2002. Casino operators dispute China corruption story. Las Vegas Sun, July 19, p. 3C.

Stutz, Howard. 2006. Sands boss Adelson sees gambling powerhouse in Cotai and Macau. Las Vegas Review Journal, May 28, p. B1.

Suizzo, Marie-Anne. 2002. French parents' cultural models and childbearing beliefs. International Journal of Behavioral Development 26 (4): 297-307.

Triandis, Harry C. 1994. Culture and social behavior. St. Louis, MO: McGraw-Hill.

Wang, Qi. 2001. Culture effects on adults' earliest childhood recollection and self-description: Implications for the relation between memory and self. Journal of Personality and Social Psychology 81 (2): 220-33

Woodside, Arch, Suresh Sood, and Kenneth E. Miller 2008. When consumers and brands talk: Storytelling theory and research in psychology and marketing. Psychology \& Marketing 25 (2): 97-125.

Zaltman, Gerald. 2003. How customers think: Essential insights into the mind of the market. Boston: Harvard Business School Press.

Kathryn A. LaTour, Ph.D., is an associate professor of hospitality marketing at the University of NevadaLas Vegas (Kathryn.latour@unlv.edu). Franck Sarrazit is senior vice president and director of Synovate Censydiam, a marketing research and consulting company (Franck.Sarrazit@synovate.com). Rom Hendler is vice president of strategic marketing at the Venetian (rom.hendler@venetian.com). Michael S. LaTour, Ph.D., is professor and chair of the marketing department at the University of Nevada-Las Vegas (Michael. latour@unlv.edu). The authors thank the Venetian for covering the direct costs of this study (such as recruiting fees). 